\title{
Calibration of a nutrient flow model of energy utilization by growing pigs
}

\author{
Stephen Birkett* and Kees de Lange \\ Department of Animal and Poultry Science, University of Guelph, Guelph, Ontario, Canada N1G 2W1 \\ (Received 31 October 2000 - Revised 1 June 2001 - Accepted 5 July 2001)
}

\begin{abstract}
A computational framework to represent energy utilization for body protein and lipid accretion by growing pigs is presented. Nutrient and metabolite flows, and the biochemical and biological processes which transform these, are explicitly represented in this nutritional process model. A calibration procedure to adjust the marginal input-output response is described, and applied, using reported experimental results, to determine a complete set of parameters for representing energy utilization by growing pigs. A reasonable value for minimum basal energy requirements is also determined. Although model inputs and outputs need not at any time be converted to equivalent energy flows, to facilitate comparison of model response with that of conventional energy-based models, a simple means to estimate energy flows from model-predicted nutrient flows is described. The well-known hierarchy of marginal (biological) energetic efficiencies with which pigs use different classes of nutrients is predicted by the model, based only on simple biological and biochemical principles. The significance of independent diet and metabolic effects on both energetic efficiency and maintenance requirements is examined using model predictions from simulated experiments.
\end{abstract}

Modelling: Nutrient flows: Calibration: Growing pigs

A conceptual framework for representing nutrient utilization by animals was presented in Birkett \& de Lange $(2001 a)$. Based on this approach a computational structure with parameters applicable to growing monogastric animals was developed (Birkett \& de Lange, 2001b). This model explicitly represents the material flows and transformations of nutrients and derived metabolites in terms of basic and functionally distinct nutritional processes: (1) intake, the acquisition of absorbed nutrients; (2) metabolic, the conversion of absorbed nutrients to energy-yielding and anabolic substrates; (3) faecal excretion of non-digestible materials; (4) urinary excretion of non-metabolizable materials; (5) production, the synthesis, degradation, and retention of body protein and lipid; (6) basal, the residual nutrient requirements not explicitly represented in the other processes. Energy requirements to drive these processes are met by ATP generated from the metabolite pools, providing a single calibration parameter for each of the main processes to adjust its input-output response. This present article describes a logical procedure for calibrating the monogastric model for a particular species, and applies this to derive appropriate parameters for a fully calibrated nutrient flow model of energy utilization by growing pigs.

\section{Calibration parameters}

Nutrient response for the primary pathways (Fig. 1) can be adjusted with six calibration parameters (Table 1). ATPd determines energy requirements for intake, digestion, and absorption of nutrients from faecal digestible DM (fDM). Intake of non-digestible DM (xDM) and its excretion as waste faecal material requires energy expressed in terms of ATPx. Faecal digestible nutrient intake is characterized in terms of crude protein (CP), crude fat (CFA), starch (ST), sugars (SU), and NSP. Ileal digestible amino acid (iAA) intake represents enzymatically-digested AA, which can meet basal AA requirements, provide the substrate for body protein retention $(\mathrm{Pd}, \mathrm{g} / \mathrm{d})$ or are catabolized. Energy requirements that are (incrementally) related to $\mathrm{Pd}$ are represented by ATPp, including energy for protein retention and any associated metabolic processes that are incrementally dependent on production level, but excluding those associated with nutrient intake and faecal and urinary excretion. The energy requirements for urinary excretion are expressed in terms of ATPu and represent the excretion of $\mathrm{N}$ from all sources, and other products in urine. Synthesized triacylglycerol from either newly synthesized fatty acids

\footnotetext{
Abbreviations: AA, amino acid; ACA, acetyl-CoA; BE, basal free energy expenditure; BW, body weight; CFA, crude fat; CP, crude protein; DE, digestible energy; f, faecal digestible; FA, Fatty acid; FS, fermentable substrate; GL, glucose; i, ileal digestible; Ld, lipid retained; ME, metabolizable energy; Pd, protein retained; REL, retained energy in lipid; REP, retained energy in protein; ST, starch; SU, sugar; uN, urinary nitrogen; VFA, volatile fatty acid; $\mathrm{x}$, non-digestible.
}

* Corresponding author: Dr Stephen Birkett, fax +1 519836 9873, email birketts@wright.aps.uoguelph.ca 


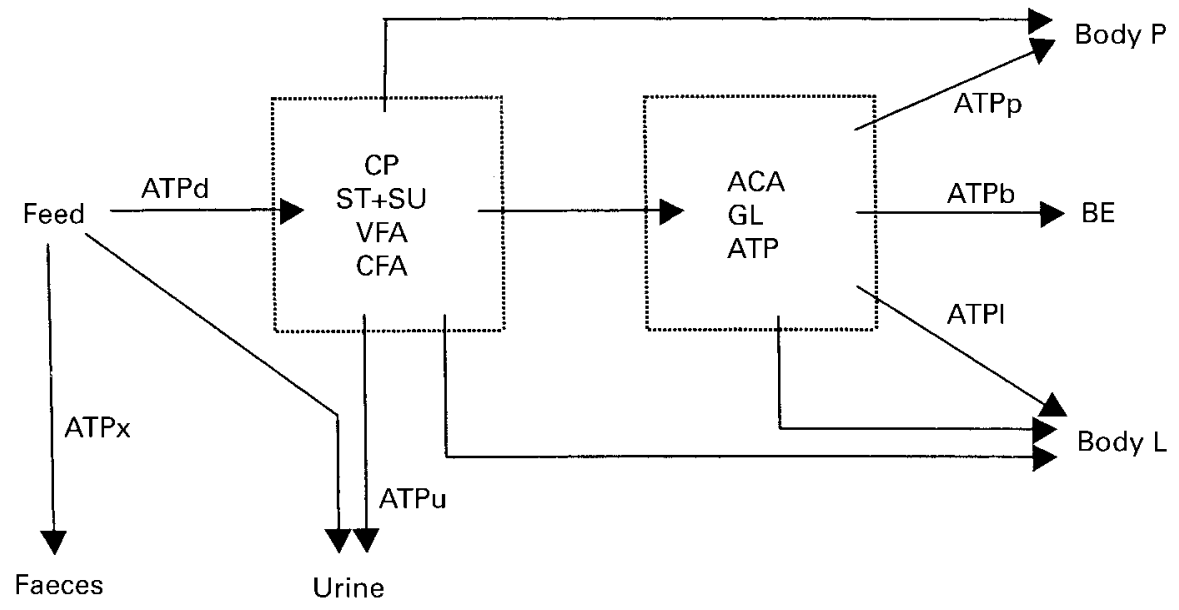

Fig. 1. Calibration parameters and main nutrient pathways. ATPd, intake, digestion, and absorption of nutrients; ATPx, processing of faecal non-digestible DM; ATPu, synthesis and excretion of urinary products; ATPI, lipid retention from both dietary and de novo sources; ATPp, protein retention; ATPb, basal ATP requirement; CP, crude protein; ST, starch; SU, sugar; VFA, volatile fatty acids; CFA, crude fat; ACA, acetyl-CoA; GL, glucose; P, protein; BE, basal free energy expenditure; L, lipid.

(FA) (assumed to be 18:1), or from dietary FA intake, is retained as body lipid $(\mathrm{Ld}, \mathrm{g} / \mathrm{d})$ with an energy requirement expressed as ATPl (mol ATP/mol Ld), applied to Ld derived from either FA source. As for protein retention, ATPI includes any associated metabolic processes that are incrementally related to $\mathrm{Ld}$ and not separately explicitly represented. ST and SU are converted directly to glucose (GL), the primary metabolite in the model. A basal requirement for ATP, representing basal free energy (BE) expenditure, is expressed in terms of the parameter $\mathrm{ATPb}$, calculated as the residual requirement after the requirements for intake, excretion, and production are taken into account. $\mathrm{BE}$ is assumed to be a function only of the animal's physical body state. Further details of the model structure can be found in Birkett \& de Lange $(2001 a, b)$.

\section{Simplifications and assumptions for growing pigs}

The representation of nutrient utilization for monogastric animals described in Birkett \& de Lange (2001b) can be simplified further when constructing a model for growing pigs. Various assumptions have been adopted for practical reasons, or because adequate information to support more complex concepts is not available:

1. Total tract digestibility of ST is usually found to be very close to $100 \%$ in pigs (Bakker, 1996; Jorgenson et al. 1996). Furthermore, ST is almost completely digested at the terminal ileum, with ileal digestibilities of 96-100\% measured for almost all ingredients. For some high-fibre diets both Bakker (1996) and Jorgenson et al. (1996) report slightly reduced ileal ST digestibilities, but never less than $95 \%$. It is therefore not unreasonable to assume a $100 \%$ ileal digestibility for ST, unless results for a particular diet indicate that ST fermentation occurs to a significant extent.

2. The simplified representation of fermentation by an energy transformation from fermentable substrate (FS) to absorbed volatile fatty acids (VFA) is adopted, as described in the general model for monogastric animals (Birkett \& de Lange, 2001b). Energetic efficiency from FS to VFA is fixed at $83 \%$ which is reasonable for pigs. Absorbed VFA are assumed to be acetic $\left(\mathrm{C}_{2}\right)$, propionic $\left(\mathrm{C}_{3}\right)$, and butyric $\left(\mathrm{C}_{4}\right)$ acids generated in the fixed molar ratios 70:25:5 (Bakker, 1996).

3. Ileal SU digestibility reported in Centraal Veevoeder Bureau (1998) is generally quite close to $100 \%$, but, for some ingredients, values are given as low as $60 \%$. It is reasonable to speculate that a lower energetic efficiency for some sugars (Noblet et al. 1989a, 1994)

Table 1. Calibration parameters for adjusting energetic response of the nutritional process model

\begin{tabular}{|c|c|c|}
\hline Symbol & Units & Biological processes \\
\hline ATPd & mol ATP/kg fDM intake & Intake of faecal digestible nutrients \\
\hline ATPx & mol ATP/kg xDM excreted & Faecal excretion of non-digested materials \\
\hline ATPu & $\mathrm{mol} \mathrm{ATP} / \mathrm{mol} \mathrm{N}$ excreted & Urinary excretion of non-metabolizable materials \\
\hline ATPp & $\mathrm{mol} \mathrm{ATP/g} \mathrm{Pd}$ & $\begin{array}{l}\text { Protein retention and related metabolic } \\
\text { processes }\end{array}$ \\
\hline ATPI & mol ATP/mol Ld & $\begin{array}{l}\text { Lipid retention and related metabolic } \\
\text { processes }\end{array}$ \\
\hline ATPb & $\mathrm{mol}$ ATP $/ \mathrm{d} / \mathrm{kg}$ body $\mathrm{P}$ & Basal energy requirement \\
\hline
\end{tabular}

fDM faecal digestible DM; xDM, non-digestible DM; Pd, protein retained; Ld, lipid retained; P, protein. 
in some diets can be attributed to an increase in SU fermentation. This is represented in the pig model and requires that diet characterization includes separate fractions for ST and SU, and measures of ileal SU digestibilities. Alternatively, the fractions consisting of iST and iSU, and fermentable ST and SU intake combined, would also be sufficient.

4. Comprehensive, meaningful data are not available to characterize diets adequately and consistently with regard to FA, for true ileal digestibilities, endogenous losses, and net synthesis and utlilization by intestinal microflora. Furthermore, ileal FA digestibilities are significantly and unpredictably affected by ingredient interactions and the FA profile (Jorgensen et al. 1992, 1993). Analytical methods, such as whether or not samples are hydrolysed prior to diethyl ether extraction, can also have a major impact on the measured digestibilities, as demonstrated by the two alternative sets of values reported in Noblet et al. (1989a). To reflect these considerations, the nutrient pathways related to CFA are simplified in the model as follows: (1) if reported faecal digestible crude fat (fCFA) is greater than iCFA, the difference, i.e. fermented fat, is ignored, and it is assumed that all fCFA is absorbed as enzymatically digested fatty acids (iFA); (2) if reported fCFA is less than the iCFA the implied net synthesis of fat is assumed to be derived on a one-to-one basis from fCFA, with no explicit energy requirement. These assumptions are accomplished by equating iCFA to fCFA and using fCFA to characterize the dietary available CFA intake.

5. Supported by the results for growing pigs reported in Birkett \& de Lange (2001b), catabolism of FA is assumed to be zero, unless intake is so low that $\mathrm{BE}$ cannot be met from non-fat nutrient sources.

\section{General calibration procedure}

Eight distinct pathways are possible for the utilization of nutrients from the four main nutrient intake classes $\mathrm{CP}$, ST+SU, NSP and CFA as energy substrates to support either $\mathrm{Ld}$ or Pd. Calibration of the marginal response with regard to these pathways consists of adjusting the five ATP parameters (ATPd, ATPx, ATPu, ATPp, and ATPl) until the incremental change in $\mathrm{Ld}$ and (or) $\mathrm{Pd}$ in response to a nutrient increment is consistent with observations from animal experiments. An implicit assumption of the nutritional process model is that the relative efficiency of utilizing energy derived from absorbed nutrients (CFA, ST, SU, AA, NSP) for synthesis of FA, as well as the generation of ATP, is determined by biochemical material conversions of metabolites: GL and acetyl-CoA (ACA). The use of absorbed nutrients to support Pd is represented by ATP requirements and material transformations of dietary AA to $\mathrm{Pd}$. As a result the hierarchy of absorbed available nutrients (other than dietary AA) to support Pd is identical to their relative ability to generate ATP. Another important assumption is that the calibration parameters are constant, i.e. that the marginal energetic response to incremental nutrient intake is independent of nutrient intake level. A careful procedure must be followed to avoid incorporating systematic errors into the model parameterization, for example because of inaccurate characterization of digestible nutrient intake or the observed retained protein and lipid in reported data. As far as possible model calibration should be based on clear experimental data which independently isolates the response pathways corresponding to each individual parameter determined.

As an alternative to calibrating nutrient response directly, an indirect approach can be used to take advantage of the extensive available literature data expressed in terms of energy flows. This requires that model variables be converted into equivalent energy flows, the product of nutrient material flow ( $\mathrm{g} / \mathrm{d}$ or $\mathrm{mol} / \mathrm{d}$ ) and nutrient energy density $(\mathrm{kJ} / \mathrm{g}$ or $\mathrm{kJ} / \mathrm{mol})$. The marginal (dietary) energetic response is defined as the ratio of the increment in retained energy (in the form of either lipid or protein) to a corresponding increment in energy intake derived from (dietary) nutrient sources. This latter approach also allows for direct comparison to conventional models representing energy utilization.

For calculating marginal energetic response, energy intake is generally expressed in terms of either digestible energy (DE) or metabolizable energy (ME) intake. The marginal energetic response to $\mathrm{ME}$ intake is determined by partitioning ME between energy retained in protein (REP) and lipid (REL), and a residual term (MEm):

$$
\mathrm{ME}=\mathrm{MEm}+\left(1 / \mathrm{k}_{\mathrm{f}}\right) \times \mathrm{REL}+\left(1 / \mathrm{k}_{\mathrm{p}}\right) \times \mathrm{REP} .
$$

Reported values for the partial efficiencies $\mathrm{k}_{\mathrm{f}}$ and $\mathrm{k}_{\mathrm{p}}$ (Table 2) exhibit wide variation, and there are various conceptual and practical problems associated with obtaining an accurate and consistent measure of ME to characterize a diet (Birkett \& de Lange, 2001a), particularly so if the incremental $\mathrm{ME}$ intake consists entirely of $\mathrm{CP}$. These considerations might imply that solid experimental data to support the proposed calibration procedure are not available, making it difficult to achieve a robust model parameterization by simulating ME partitioning. However, the problems can be largely circumvented by using experimental data in which incremental intake of pure nutrients from non-protein sources is related to REL and REP. Reported marginal efficiencies are generally highly consistent in this case, in particular for utilizing (digestible) ST or CFA for REL.

The calibration procedure mimics the statistical regression of experimental data by constructing a simulated

Table 2. Reported marginal efficiencies of utilizing metabolizable energy for retained lipid $\left(k_{f}\right)$ and protein $\left(k_{p}\right)$

\begin{tabular}{lll}
\hline $\mathrm{k}_{\mathrm{f}}$ & $\mathrm{k}_{\mathrm{p}}$ & \multicolumn{1}{c}{ Reference } \\
\hline 0.80 & 0.60 & Noblet et al. $(1989 b)$ \\
0.70 & 0.58 & Close et al. (1973) \\
0.74 & 0.56 & Agricultural Research Council (1981) \\
0.60 & 0.51 & Tess (1981) \\
0.74 & 0.45 & Pullar \& Webster (1977) \\
0.75 & 0.44 & Whittemore (1997) \\
\hline
\end{tabular}


response plane relating $\mathrm{ME}$ to REL and REP from partial linear relationships between ME and REL at fixed REP, and ME and REP at fixed REL. This procedure will be exact only when model-generated points are co-planar, i.e. the energetic response is linear with regard to both REP and REL as a function of ME intake. Consideration of the model calculation rules implies this linearity condition will generally be met exactly, or very closely, except for some situations in which the partitioning of nutrient intake between the main processes ( $\mathrm{Ld}, \mathrm{Pd}$ and ATP generation) does not change linearly with changes in nutrient intake level. This can occur, for instance, when AA intake is reduced below that required for $\mathrm{Pd}$. In the case of such nonlinear response, constant $\mathrm{k}_{\mathrm{f}}$ and $\mathrm{k}_{\mathrm{p}}$ values are not possible.

Simulation of partial marginal responses requires pure increments in either Ld or Pd, something which can easily be forced in a model simulation, even though it is practically impossible to achieve with growing animals in experiments. For example, to simulate an incremental change in REL only, ME can be incremented while maintaining the predicted $\mathrm{Pd}$ at a fixed value by (artificially) manipulating the PdMax parameter, the maximum Pd according to animal constraints. Alternatively a pure REP increment can be simulated by adjusting REP using PdMax, then adjusting ME intake until REL returns to its initial value.
Calibration of marginal response proceeds as follows: (1) the two parameters ATPd and ATPl are determined simultaneously so that simulated marginal responses for increments of (digestible) GL and CFA are consistent with reported values; (2) a value for ATPx is determined from experimental data pertaining to the energetic cost of ingesting and excreting inert material; (3) reported observations on energy derived from protein sources are then taken into account to estimate a value for ATPu; (4) a value for ATPp is determined by adjusting it until simulated response with regard to both $\mathrm{Pd}$ and $\mathrm{Ld}$ is in agreement with observed response, i.e. simulated marginal efficiency from ME to REP is adjusted until it is close to the best estimate of $\mathrm{k}_{\mathrm{p}}$ from literature values, using a simulated diet of similar composition to the experimental diets. Basal energy requirement is irrelevant when calibrating marginal response, provided the same $\mathrm{BE}$ value applies at both of the energy intake levels used to calculate the incremental $\mathrm{ME}$ intakes. Therefore any fixed value for $\mathrm{ATPb}$ can be maintained for simulations throughout the calibration procedure for marginal response.

The values reported here for the calibration parameters are intended only as reasonable estimates. Carefully controlled experiments directed at exploring the response for each nutrient pathway will be required to obtain more definitive parameter values (e.g. van Milgen et al. 2001).

Table 3. Energy densities of selected nutrients: calculated and literature values from various sources

\begin{tabular}{|c|c|c|c|c|c|}
\hline & \multicolumn{5}{|c|}{ Energy density $(\mathrm{kJ} / \mathrm{g})$} \\
\hline & $\mathrm{CP}$ & CFA & ST & SU & NSP \\
\hline Maize-soyabean meal base diet* & $23 \cdot 7$ & $39 \cdot 6$ & & & \\
\hline $100 \%$ Leucinet & $31 \cdot 7$ & & & & \\
\hline eoninet & $20 \cdot 8$ & & & & \\
\hline A† & $18 \cdot 9$ & & & & \\
\hline d lipid§ & $23 \cdot 7$ & $39 \cdot 6$ & & & \\
\hline$\|$ & $23 \cdot 1$ & & & & \\
\hline ein? & $23 \cdot 3$ & & & & \\
\hline$d^{\star \star}$ & 23.5 & $39 \cdot 3$ & & & \\
\hline$\dagger$ & $23 \cdot 8$ & $39 \cdot 6$ & & & \\
\hline 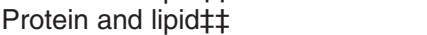 & $23 \cdot 6$ & $39 \cdot 3$ & & & \\
\hline Pure & & & $17 \cdot 35$ & $15 \cdot 6-16 \cdot 5$ & \\
\hline Dietary nutrients|||| & $\begin{array}{r}22.37 \\
\text { (SE 0.72) }\end{array}$ & $\begin{array}{c}38.70 \\
\text { (SE } 0.89)\end{array}$ & $\begin{array}{c}17.34 \\
(S E 0.21)\end{array}$ & $\begin{array}{c}16.69 \\
\text { (SE 0.65) }\end{array}$ & $\begin{array}{c}18.46 \\
\text { (SE 0.46) }\end{array}$ \\
\hline Digestible dietary nutrients|||| & $23 \cdot 17$ & $\begin{array}{r}39.06 \\
\end{array}$ & 17.35 & $16 \cdot 78$ & $16 \cdot 19$ \\
\hline Values used in model calibration & $\begin{array}{c}(\mathrm{SE} 0.49) \\
23 \cdot 3\end{array}$ & $\begin{array}{c}(\text { SE } 0.10) \\
39 \cdot 3\end{array}$ & $\begin{array}{c}(\operatorname{SE} 0.14) \\
17 \cdot 35\end{array}$ & $\begin{array}{l}(0.40) \\
16 \cdot 8\end{array}$ & $\begin{array}{c}(S E 0.53) \\
16 \cdot 2\end{array}$ \\
\hline \multicolumn{6}{|c|}{ 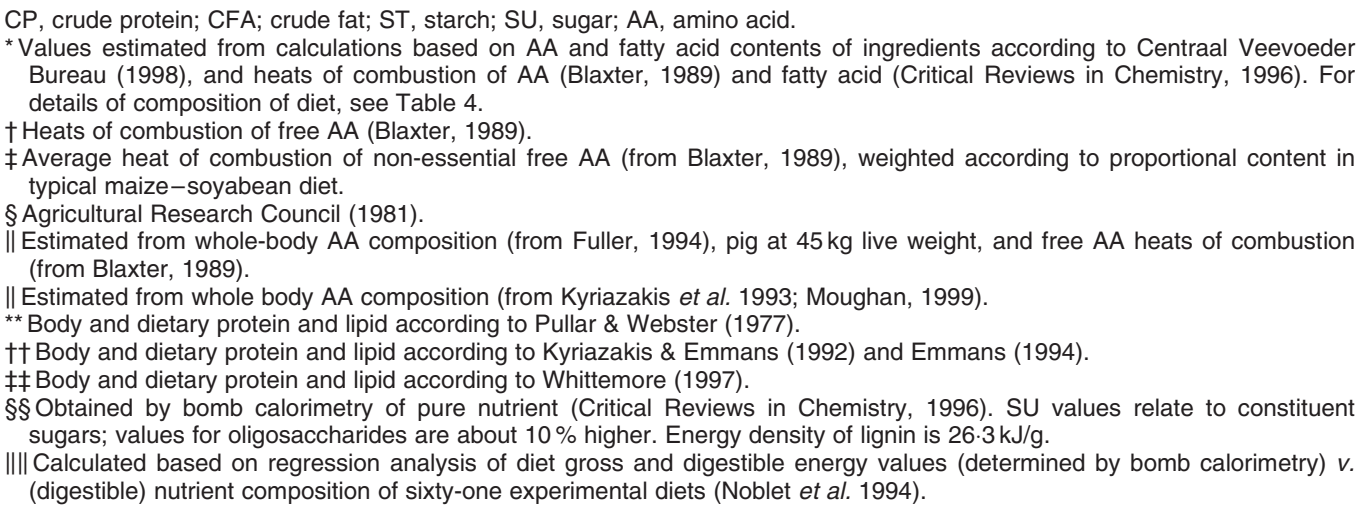 } \\
\hline
\end{tabular}




\section{Simulation of energy intake and retention}

\section{Simulation of digestible energy intake}

For comparing the response of the nutritional process model to that of conventional models of energy utilization in growing pigs, energy intake and retention need to be simulated. Based on the intake and nutrient composition of the diet, fDM $(\mathrm{kg} / \mathrm{d})$ is converted to a DE intake $(\mathrm{kJ} / \mathrm{d})$ using fixed values for the energy densities $(\mathrm{kJ} / \mathrm{g})$ of the main nutrient classes, for which various values are reported in Table 3.

The energy content of free AA varies widely, from $31.7 \mathrm{~kJ} / \mathrm{g}$ for leucine, to $20.8 \mathrm{~kJ} / \mathrm{g}$ for threonine, and an average value of $18.9 \mathrm{~kJ} / \mathrm{g}$ representing the weighted mean of non-essential AA. Thus one can expect variation in the energy density of $\mathrm{CP}$ according to AA composition, and particularly because of variation in the non-essential AA content of the CP. A value of $23.7 \mathrm{~kJ} / \mathrm{g} \mathrm{CP}$ is estimated for a typical pig diet, while a somewhat lower value of $23.3 \mathrm{~kJ} / \mathrm{g}$ is obtained from regression analysis of DE contents for the sixty-one practical diets of Noblet et al. (1994). Whole-body $\mathrm{CP}$ in pigs is estimated to have an energy density of $23 \cdot 1-$ $23 \cdot 3 \mathrm{~kJ} / \mathrm{g}$, using the whole-body AA composition reported from different sources (Blaxter, 1989; Kyriazakis et al. 1993; Moughan, 1999). Even though there are clearly differences between the energy density of dietary as compared with body $\mathrm{CP}$, a common value is generally used as a compromise: $23 \cdot 3 \mathrm{~kJ} / \mathrm{g}$ has been assumed for the energy density of both dietary $\mathrm{CP}$ and $\mathrm{Pd}$ in the calibration of the model for growing pigs. These same considerations can be applied to CFA, which will vary (to a lesser extent than $\mathrm{CP}$ ) with FA composition. In the calibration a common value of $39 \cdot 3 \mathrm{~kJ} / \mathrm{g}$ is used for the energy density of both dietary CFA and body Ld.

Energy densities obtained for ST are very consistent, which is important because ST makes up the major energy component in many pig diets, and ST is used for a critical step in model calibration. For SU intake the heats of combustion of pentoses and hexoses are less than $16 \mathrm{~kJ} / \mathrm{g}$ : fructose, glucose, galactose, arabinose, xylose are all about $15.6 \mathrm{~kJ} / \mathrm{g}$, while values for lactose and sucrose are higher at $16.5 \mathrm{~kJ} / \mathrm{g}$ (Critical Reviews in Chemistry, 1996). The high average value $16.8 \mathrm{~kJ} / \mathrm{g}$ obtained for $\mathrm{SU}$ in the regression (Table 3) reflects the fact that pure sugars will be present in the nutrient fraction as oligosaccharides, which have energy densities greater than those of their constituent sugars in the same way that the heat of combustion of ST $(17 \cdot 35 \mathrm{~kJ} / \mathrm{g})$ is higher than that of its constituent sugar glucose $(15.64 \mathrm{~kJ} / \mathrm{g})$. SU content in commercial pig diets is generally $<100 \mathrm{~g} / \mathrm{kg}$ diet, and the composition is variable and generally unknown, so the assumed average value of $16.8 \mathrm{~kJ} / \mathrm{g}$ appears to be a reasonable estimate. Variation in the composition of the NSP fraction will significantly affect its energy density; the difference between gross energy and DE densities determined for NSP can probably be attributed to different compositions of digestible and non-digestible fractions. For instance, the very low digestibility of lignin implies that most lignin present in gross energy will not contribute to DE. The heat of combustion of lignin $(26.3 \mathrm{~kJ} / \mathrm{g})$ is much higher than that of the other carbohydrates, which largely explains the higher values

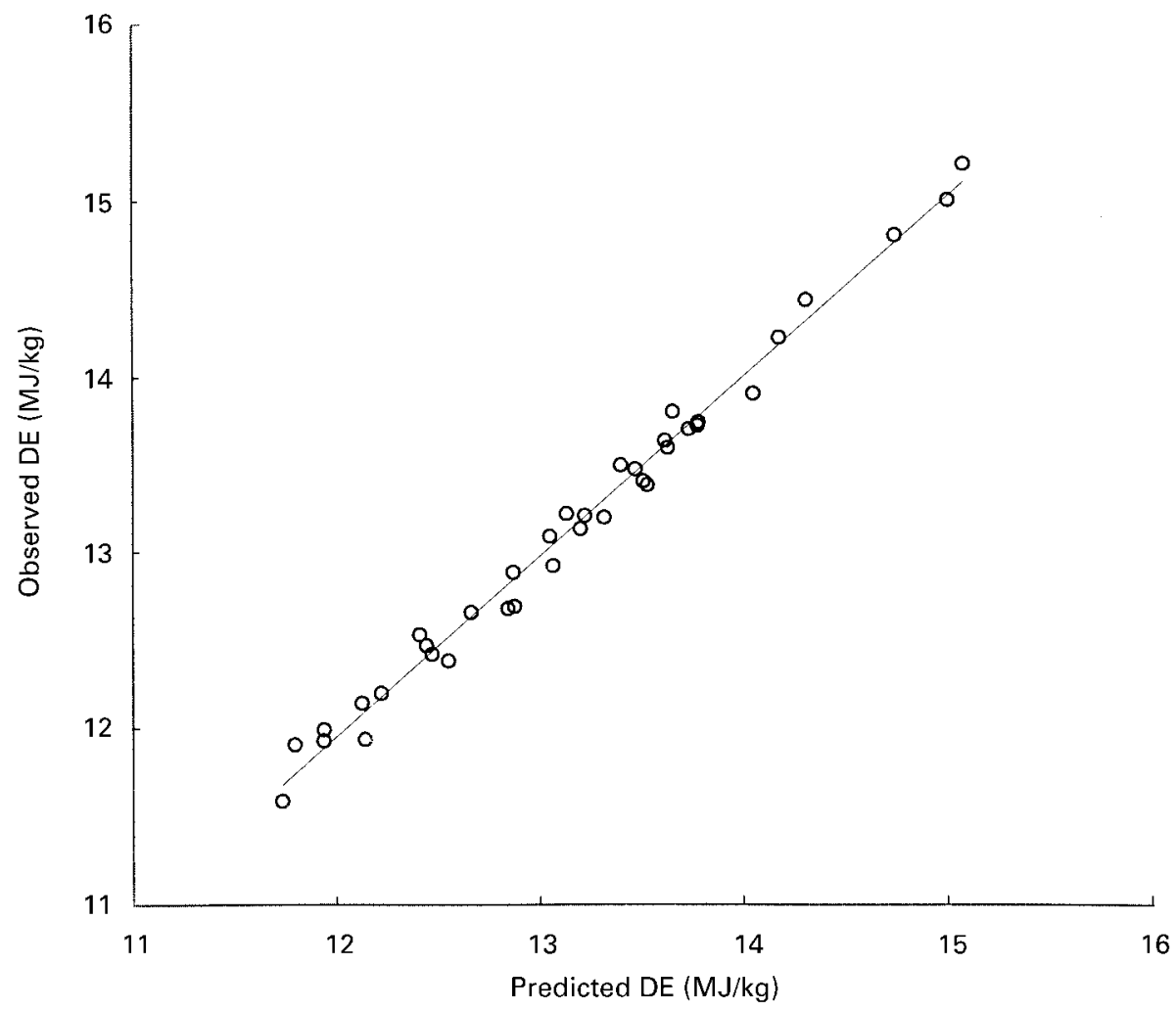

Fig. 2. Simulated diets from Noblet et al (1989a). Predicted $v$. observed digestible energy (DE) values $\left(y=1.03 x-0.35, R^{2} 0.99\right)$. 
obtained for NSP as compared with fNSP. Calculating the contribution of NSP to DE using a fixed average energy density is a reasonable approximation in the absence of further information on its composition.

To evaluate the prediction of DE content, diets were simulated using the stated ingredient compositions of the forty-one experimental diets of Noblet et al. (1989a), and ingredient nutrient composition data from Centraal Veevoeder Bureau (1998). The reported observed DE values are in good agreement (Fig. 2) with those predicted by calculation using the nutrient energy densities derived earlier, which may therefore be used with reasonable confidence in further comparison of model predictions to those of conventional energy-based models. It should be emphasized that the calibration procedure itself has been designed to rely only on the energy density values of CFA and ST, which are very well established and less variable than those of the other feed nutrients.

\section{Simulation of metabolizable energy intake}

To estimate simulated diet ME content for the nutritional process model requires an estimate of urinary and $\mathrm{CH}_{4}$ energy losses. For pigs, simulated $\mathrm{CH}_{4}$ energy losses are generally much smaller than urinary losses, and therefore, a reasonable enough estimate can be obtained from FS intake adapted from an equation of Kirchgeßner et al. (1991):

$$
\begin{aligned}
\mathrm{CH}_{4} \text { energy loss }(\mathrm{kJ} / \mathrm{d})= & 160+0.041 \times \mathrm{E}(\mathrm{FS}) \\
& (\mathrm{kJ} / \mathrm{d}), R^{2} 0.59
\end{aligned}
$$

where $\mathrm{E}(\mathrm{FS})$ is the energy intake in FS calculated using the energy densities estimated earlier.

For estimating urinary energy content, a relationship with urinary $\mathrm{N}(\mathrm{uN})$ content is often used, even though this is not strong (see discussion in Birkett \& de Lange, 2001a). A multiple regression with urinary $\mathrm{C}$ and $\mathrm{N}$ gives a better predictor for urinary energy (Hoffmann \& Klein, 1980), however, since urinary $\mathrm{C}$ excretion is not predicted in the model, urinary energy content must be estimated from the simulated $\mathrm{uN}$. For the calibration procedure a fixed value of $47.5 \mathrm{~kJ} / \mathrm{g} \mathrm{uN}$ (estimate from Hoffmann \& Klein, 1980) is used and applied to $\mathrm{uN}$ derived from any source. The implications of variation in assumed urinary energy content are discussed in some detail below.

\section{Simulated diet}

The base diet used for simulations, with nutrient composition shown in Table 4, is formulated to represent a typical corn-soyabean meal pig diet. Simulated DE content is $14.25 \mathrm{~kJ} / \mathrm{g}$ and lysine:CP ratio is 0.05 . To avoid the non-linear response region, intake is determined so that nutrient supply is always sufficient to meet the requirements for the selected Pd level.

\section{Calibration of marginal energetic response for pigs \\ Intake of faecal digestible nutrients (ATPd) and lipid deposition (ATPl)}

The energetic efficiency of utilizing digestible dietary fat for Ld is consistently reported to be about 90\% (Boyd \& McCracken, 1979; Black, 1995; Whittemore, 1997), a value which implies a very low level of dietary fat catabolism. For supplemental intakes of ST and SU (GL, fructose, sucrose and lactose) the marginal energetic efficiency for $\mathrm{Ld}$ is reported to be $75 \%$ by Knox (1979), quoting Nehring et al. (1965), consistent with the efficiencies for ST and SU of between 74 and $76 \%$ given in both Armstrong (1969) and Black (1995). The first stage of model calibration is

Table 4. Nutrient composition of maize-soyabean meal base diet used

\begin{tabular}{|c|c|c|c|}
\hline & \multirow{2}{*}{$\begin{array}{c}\text { Content } \\
\text { (g/kg as fed) }\end{array}$} & \multicolumn{2}{|c|}{$\begin{array}{l}\text { Digestible content } \\
\text { ( } \mathrm{g} / \mathrm{kg} \text { as fed) }\end{array}$} \\
\hline & & Apparent faecal & True ileal \\
\hline DM & 871 & 787 & \\
\hline Crude protein & 175 & 149 & 146 \\
\hline Crude fat & 32 & 22 & \\
\hline Starch & 463 & 463 & 463 \\
\hline Sugars & 32 & 32 & 27 \\
\hline NSP & 127 & 82 & \\
\hline Lysine & 8.5 & & $7 \cdot 3$ \\
\hline Methionine & $2 \cdot 8$ & & 2.5 \\
\hline Methionine+cystine & $5 \cdot 8$ & & $5 \cdot 0$ \\
\hline Tryptophan & $1 \cdot 8$ & & $1 \cdot 6$ \\
\hline Histidine & 4.8 & & $4 \cdot 3$ \\
\hline Phenylalanine & $8 \cdot 6$ & & $7 \cdot 6$ \\
\hline Phenylalanine+tyrosine & $14 \cdot 9$ & & $13 \cdot 1$ \\
\hline Threonine & $6 \cdot 5$ & & $5 \cdot 4$ \\
\hline Leucine & $15 \cdot 9$ & & $14 \cdot 0$ \\
\hline Isoleucine & $7 \cdot 2$ & & $6 \cdot 3$ \\
\hline Valine & $8 \cdot 2$ & & $7 \cdot 1$ \\
\hline Arginine & $11 \cdot 0$ & & $10 \cdot 1$ \\
\hline
\end{tabular}
for calibration simulations*

* Simulated digestible energy content $14 \cdot 25 \mathrm{~kJ} / \mathrm{g}$. 
therefore based on achieving a simulated marginal energetic efficiency of $90 \%$ for lipid retention from an increment of digestible CFA intake, and $75 \%$ from digestible (nonfermented) ST and SU intake. This is accomplished by simultaneously adjusting the parameters ATPl and ATPd to find the unique solution for which the simulated marginal energetic efficiencies for Ld agree with these assumed values. The value of ATPx has a negligible influence on these simulated efficiencies and may be set to zero while adjusting ATPd and ATPl, because: (1) the digestibility of pure ST can reasonably be assumed to be $100 \%$; (2) due to the high energy density of CFA, moderate differences in digestibility have little effect on the simulated efficiency for CFA. The calibration of ATPd and ATPl is therefore essentially independent of ATPx.

After adjusting the two calibration parameters to obtain the assumed model response for incremental intakes of CFA and ST, ATPl is found to be $30 \mathrm{~mol} \mathrm{ATP} / \mathrm{mol}$ lipid retained and ATPd is $28 \mathrm{~mol} \mathrm{ATP} / \mathrm{kg} \mathrm{fDM}$. The minimum stoichiometric ATP requirement for synthesizing body lipid from FA and GY implies a (theoretical minimum) value for ATPl of $10 \mathrm{~mol} / \mathrm{d}$ per mol lipid retained (Birkett \& de Lange, 2001b). The calibrated value obtained for ATPd is therefore about three times the theoretical minimum for synthesis of Ld. Intake energy requirements as determined by the calibrated value for ATPd are quite large, and typically correspond to an ME cost of about $12-14 \%$ total ME intake for the diet compositions of Noblet et al. (1989a).

\section{Faecal excretion of non-digested materials (ATPX)}

Müller \& Kirchgeßner (1982) report an observed linear depressive effect on REL of $0.08 \mathrm{~kJ}$ in response to each $\mathrm{kJ}$ increment of 'non-digestible' straw added to a basal diet (energy digestibility for the straw supplement was $13 \%$ ). This data can be used to provide an independent estimate for the energy requirement of processing undigested $\mathrm{xDM}$. Simulated straw increments were added to the DM intake of the base diet, and ATPx was adjusted until the simulated negative response in REL agreed with the experimental value reported. This procedure provides an estimated value for ATPx of $20 \mathrm{~mol} \mathrm{ATP} / \mathrm{kg}$ xDM. The energy requirements for processing $\mathrm{xDM}$ correspond to an ME cost of up to about $3 \%$ total ME intake for the simulated treatments of Noblet et al. (1989a). On an energy basis the cost of processing $\mathrm{xDM}$ is typically about $10-12 \%$ energy of the excreted $\mathrm{xDM}$ itself $(\mathrm{kJ} / \mathrm{kJ} \mathrm{xDM})$, and this value varies with the energy density of xDM.

The independent estimates derived for ATPx and ATPd are consistent and imply that physical processing of nutrient intake accounts for about $70 \%$ of the overall intake costs. This energy for intake processing must be provided whether or not the nutrients are eventually absorbed and subsequently metabolized. Carefully controlled experimental work is required to arrive at a definitive value for ATPx, but the present value will serve as a reasonable estimate, as confirmed by independent testing of direct model reponse to nutrient intake, using reported data from the forty-one diets of Noblet et al. (1989a), with widely varying non-digestible components (see Fig. 3).
Urinary excretion of non-metabolizable materials (ATPu)

Marginal efficiency is less easy to quantify for utilizing CP as an energy substrate, i.e. to generate the ATP and ACA to support Ld. For example, it is significantly affected by the AA composition of the protein, on account of the wide variation in biochemical efficiency of oxidation for different AA (Birkett \& de Lange, 2001b). Reported experimental data generally relate to the measured response in terms of REL, rather than the marginal efficiency of ATP production per se. Kielanowski (1971) reports efficiencies of using CP intake for Ld in the range of 60-65\%, while Black (1995) and Whittemore (1997) both give a somewhat lower efficiency of $52-53 \%$. These values include the energetic effects of intake requirements, urea synthesis and urinary excretion, biochemical inefficiency of AA catabolism, and lipid retention. The actual ME cost related to urea excretion includes support costs for the excretion of both the $\mathrm{N}$ and the non-nitrogenous components of urine, various transport and metabolic processes that occur in the urea cycle, and other metabolic processes which are associated with urinary excretion (Birkett \& de Lange, 2001b). Nevertheless, the $\mathrm{ME}$ cost for urinary excretion is closely related to $\mathrm{uN}$, consistently reported to be about three times the theoretical value implied by the biochemical stoichiometry of urea synthesis. The parameter ATPu is therefore fixed in relation to the rate of $\mathrm{uN}$ excretion at $6 \mathrm{~mol} \mathrm{ATP} / \mathrm{mol} \mathrm{uN}$. Based on the previously determined values of ATPd, ATPl, and ATPx, this assumption provides a simulated marginal energetic efficiency of $56 \%$ for REL derived from incremental dietary CP intake of the same AA composition and digestibility as that of the base diet, in agreement with the values reported earlier in the range of 50-65\%.

\section{Fermentation}

The marginal energetic efficiency for lipid retention from hindgut infusions of VFA is reported to be $65-71 \%$ (Gädeken et al. 1989), 75-79\% (Roth et al. 1988), and $70 \%$ (Müller \& Kirchgeßner, 1991). The nutritional process model can be used to provide a simulated estimate for these experimental values by setting: (1) the fermentation efficiency factor temporarily to $100 \%$, so that an 'NSP supplement' then corresponds actually to a VFA supplement; (2) the ATPd parameter to zero, removing the intake costs and simulating a pure nutrient infusion into the hindgut. Faecal digestibility of VFA is close to $100 \%$ (Kirchgeßner \& Müller, 1991; Bakker, 1996) so simulations are not sensitive to ATPx. With these adjustments a simulated marginal energetic efficiency of $75 \%$ is obtained, in good agreement with the observed experimental values cited earlier. (Actually a relatively small portion of the ATPd requirement will still apply to meet the energetic cost of absorption of VFA, so this simulated efficiency should be somewhat less.) Returning ATPd to the value determined in the calibration above lowers the simulated marginal efficiency to $63 \%$, a situation corresponding to dietary supplements of VFA which require ingestion, digestion, and absorption. Finally, returning the fermentation efficiency for deriving VFA from NSP to the assumed value of $83 \%$, a value of $53 \%$ is obtained from the model for the marginal 
efficiency of utilizing digestible NSP for REL. The faecal digestibility of NSP is very variable, typically not exceeding 60-65\% (Centraal Veevoeder Bureau, 1998), so a further (variable) reduction in simulated efficiency can be expected due to the effect of $x D M$ and ATPx. The marginal energetic efficiency is lowered, for instance, to about $48 \%$ for an NSP digestibility of $60 \%$. The implied range of simulated values for the marginal efficiency of utilizing ME from digestible NSP for REL is consistent with the range of the values reported in the literature: $43 \%$ (Bakker, 1996), 59-63\% (Schiemann et al. 1989), 41-64\% (Kirchgeßner \& Müller, 1991), 56\% (Jentsch et al. 1988), 59\% (Longland et al. 1989). These considerations indicate that no separate calibration parameter is required to represent the fermentation process adequately.

\section{Protein retention (ATPp)}

The biochemical stoichiometry of protein synthesis includes AA activation, initiation of peptide chain formation, elongation and termination. Armstrong (1969), Schulz (1978), van Es (1980), McDonald et al. (1995), and Blaxter (1989) all report energy requirements of 4-5 mol ATP for synthesizing $1 \mathrm{~mol}$ peptide bonds from constituent AA. Protein synthesis thus requires a minimum ME cost of some $4 \mathrm{~kJ} / \mathrm{g} \mathrm{Pd}$, based on an estimated ME equivalent cost of $77 \mathrm{~kJ} / \mathrm{mol}$ ATP and an average molar weight of $110 \mathrm{~g} / \mathrm{mol}$ for body protein. Reeds et al. (1980) estimate that protein synthesis typically occurs at a rate between two and three times Pd, which suggests a minimum ME cost of between about 8 and $12 \mathrm{~kJ} / \mathrm{g} \mathrm{Pd}$. Assuming no other requirement for energy would imply a maximum $\mathrm{k}_{\mathrm{p}}$ of about $0 \cdot 7$, greater than any of the values reported in Table 2 , which vary between about 0.44 and 0.60. Increments in various metabolic processes associated with an increase in Pd are likely responsible for observed $\mathrm{k}_{\mathrm{p}}$ values significantly lower than the theoretical (maximum) $\mathrm{k}_{\mathrm{p}}$ value of 0.7. Reeds et al. (1980) estimate a value for $\mathrm{k}_{\mathrm{p}}$ of about $0 \cdot 46$, consistent with Webster et al. (1979), who estimate a heat increment associated with protein deposition of between 20 and $50 \%$ total heat production, giving $52 \mathrm{~kJ} / \mathrm{g}$ Pd using the mean of $35 \%$, or a $k_{p}$ of 0.45 . This value is also similar to the reported $k_{p}$ of 0.44 in Pullar \& Webster (1977), using rats fed a highly digestible, high protein $(250 \mathrm{~g} \mathrm{CP} / \mathrm{kg})$, synthetic diet, and a sophisticated experimental design that reduces the instability related to multi-collinearity in the regression analysis (Birkett \& de Lange, 2001a).

Based on these considerations, and using a simulated high-protein diet $(250 \mathrm{~g} \mathrm{CP} / \mathrm{kg})$, the value of ATPp is adjusted until the simulated marginal energetic efficiency of using ME for Pd, i.e. the simulated $\mathrm{k}_{\mathrm{p}}$ value, is 0.47 . To avoid a non-linear response, care must be taken to ensure that protein retention at each level simulated is limited only by PdMax and not by AA intake. A value of $0.28 \mathrm{~mol} / \mathrm{g} \mathrm{Pd}$ is obtained for growing pigs when ATPp is adjusted until the simulated model marginal efficiency agrees with the assumed value. The minimum (theoretical) requirement for protein synthesis, $11 \mathrm{~mol} \mathrm{ATP} / \mathrm{g} \mathrm{Pd}$, and a typical synthesis rate of 2.2 times Pd (Reeds et al. 1980), would imply a value for ATPp of $0 \cdot 10 \mathrm{~mol} / \mathrm{g} \mathrm{Pd}$, therefore the estimated value is about three times the theoretical one (as for ATPI).

There are, of course, some limitations to this calibration method for ATPp: the reported values for energetic efficiency $\mathrm{k}_{\mathrm{p}}$ are quite variable (Birkett \& de Lange (2001a); any assumption regarding $\mathrm{k}_{\mathrm{p}}$ will ultimately influence the absolute model response (BE requirement); and it is assumed that the relative marginal efficiencies of using ME for REP are the same as those for supporting REL. Until more specific, highly controlled experimental data are available, the approach using simulated efficiency is probably the most reliable. Nevertheless, the estimate obtained for ATPp may be independently evaluated by comparing simulated and observed $\mathrm{Ld}$ and Pd response to nutrient intake using available datasets, without any need to consider partial efficiencies and the various problems associated with that concept (see p. 683).

\section{Calibrating absolute energetic response}

The last parameter $(\mathrm{ATPb})$ representing $\mathrm{BE}$ is estimated based on comparing the absolute model-generated response, i.e. absolute $\mathrm{RE}$ in response to $\mathrm{ME}$ intake, to experimental observations (Birkett \& de Lange, 2001b). Variation in BE can be anticipated, since it represents the residual energy expenditure. As a result, the practical application of the nutritional process model for predicting the growth of specific groups of animals under particular on-farm conditions will require $\mathrm{ATPb}$ to be adjusted so model predictions match production data for those specific conditions and animals. This provides a means to calibrate the model further for a particular (geno)type and production conditions, a procedure which is conceptually equivalent to adjusting maintenance energy when calibrating an energybased model for particular on-farm conditions (de Lange \& Schreurs, 1995). Therefore, the approach taken here is to determine a minimal $\mathrm{BE}$ (BEmin) as a function of the body protein content (Pbody), with pigs kept under low levels of activity in stress-free and thermoneutral conditions (Birkett $\&$ de Lange, 2001b).

To illustrate the calibration of $\mathrm{ATPb}$ a minimum value was estimated using experimental data reported in Quiniou (1995), pertaining to pigs raised individually in metabolism crates. In this study $\mathrm{N}$ balances and energy expenditure measurements for three different genotypes $(\mathrm{LP} \times \mathrm{PP}$ castrates, LW castrates, $\mathrm{LW} \times \mathrm{PP}$ boars) are given at four different target live body weights (BW) $(45,65,80$ and $95 \mathrm{~kg})$ for four different ME intake levels, expressed as 71, 80, 90 and $100 \%$ voluntary ME intake, as determined by Quiniou (1995) for each genotype. Chemical body composition, in particular empty body protein (Pbody) and lipid content, is reported at only the lowest and highest BW. Diets used for the different energy intake treatments are based on a common base diet, mixed at varying proportions with cornstarch. Simulated diets were formulated with the nutrient compositions stated in Quiniou (1995). Each of the treatments in experiment 3 of Quiniou (1995) was simulated using a dynamic growth model with an energy component based on the nutritional process model with marginal energetic response calibrated as described earlier.

Quiniou (1995) reports feed intake only at the target 
BW, therefore feed intakes were represented with (model) calculated DE intake expressed as a percentage of reference National Research Council (1987) intake, adjusted for each simulation so that the (model) calculated $\mathrm{ME}$ intake at the target $\mathrm{BW}$ was identical to the reported $\mathrm{ME}$ intake for that BW. Furthermore, PdMax was adjusted to (artificially) force $\mathrm{Pd}$ into agreement with the reported value for that $\mathrm{BW}$. Finally the value of $\mathrm{BE}$ was adjusted using $\mathrm{ATPb}$ until Ld was in agreement with the reported value when simulated $\mathrm{BW}$ was the target weight. This procedure ensures that all of the simulated ME intakes, $\mathrm{Pd}$ and $\mathrm{Ld}$ are the same as those reported for 45, 65, 80 and $95 \mathrm{~kg} \mathrm{BW}$. For each of these target weights, and for each energy intake level and genotype, the simulated residual BE requirement (mol ATP/d), and values of Pbody, BW and empty BW were obtained, a total of 48 points.

For each treatment, estimates for BE at the target BW were generated from simulations. These $\mathrm{BE}$ values were then correlated with variables that reflect the animal's body state, in particular Pbody, BW, and empty BW. Since Pbody is not reported at the two intermediate BW, it must be estimated with the model from predicted body composition at 65 and $80 \mathrm{~kg} \mathrm{BW}$, which requires growth simulation for four separate periods $(20 \mathrm{~kg} \mathrm{BW}$ was used as a starting weight) ending with each of the target weights.

Regression analysis was then used to relate $\mathrm{BE}$ to the body state variables. Each of Pbody, empty BW and BW is highly correlated with generated BE values, the best fit being obtained from a linear model with Pbody, with significant genotype specific (non-zero) intercept and slope. A reasonable estimate of $\mathrm{BE}$ for barrows can be obtained using the thirty-two combined model-generated points at $\mathrm{BW}$ of $45,65,80$ and $95 \mathrm{~kg}$ for the two castrate genotypes. Linear and allometric models tested gave the following relationships:

$$
\begin{aligned}
& \text { BEmin }(\operatorname{mol} \text { ATP } / \mathrm{d})=40 \cdot 4+4.23 \text { Pbody }(\mathrm{kg}), \\
& \mathrm{R}^{2} 0 \cdot 97, \text { SEM } 2 \cdot 37, \\
& \text { BEmin }(\operatorname{mol} \mathrm{ATP} / \mathrm{d})=23.8 \text { Pbody }(\mathrm{kg})^{0.54}, \\
& \mathrm{R}^{2} 0 \cdot 96, \text { SEM } 2 \cdot 53,
\end{aligned}
$$

which are indistinguishable in the experimental range 45$95 \mathrm{~kg} \mathrm{BW}$, although they diverge outside that range. Further evaluation comparing simulations and experimental data at BW below $45 \mathrm{~kg}$ and above $95 \mathrm{~kg}$ will be required to determine which BEmin regression is more appropriate, and to obtain more definitive values for the coefficients, although these will likely remain genotype specific.

\section{Discussion}

The practical use of the nutritional process model for quantitative simulation does not require conversion of nutrient intakes, retained protein and lipid, or ATP requirements, to their energy equivalents, even though energy flows were used for convenience in the calibration procedure. Nevertheless, to provide a basis for comparison of predictions to those of conventional energy-based models in the following discussion it is useful to be able to estimate $\mathrm{ME}$ equivalent costs for meeting simulated ATP requirements, i.e. the heat production associated with generating the ATP from dietary nutrient sources. The free energy released in vivo by breaking a high energy ATP bond varies somewhat according to thermodynamic conditions relating to temperature and the intercellular concentrations of ATP and ADP, but free energy is generally considered to be about 52 kJ/mol ATP (Burton, 1958; Armstrong, 1969). The nutrient composition of the ME used to generate ATP will affect the energetic efficiency, for example 74, 78 and $93 \mathrm{~kJ}$ $\mathrm{ME} / \mathrm{mol}$ ATP being reported for ATP derived from GL, FA, and VFA respectively (Armstrong, 1969; van Es, 1980). For ME derived from the base diet of Table 4 an efficiency of 0.69 is predicted for generating ATP, equivalent to an ME cost of $75 \mathrm{~kJ} / \mathrm{mol} \mathrm{ATP}$, and that value is assumed in the following discussion.

\section{Marginal energetic response}

Simulated marginal energetic efficiencies for deriving REL from ME are summarized in Table 5 for the main nutrient classes. These include values for the following scenarios: biochemical synthesis of lipid, pure nutrient infusions, dietary supplements assumed to be $100 \%$ digestible, and supplements with typical practical digestibilities. Simulated

\begin{tabular}{|c|c|c|c|c|c|c|c|c|c|}
\hline & \multicolumn{4}{|c|}{ Calibration parameters } & \multicolumn{5}{|c|}{ Simulated marginal efficiency ME to REL (\%) } \\
\hline & ATPd & $\operatorname{ATP}_{\mathrm{x}}$ & ATP $_{u}$ & ATPI & CFA & ST & $\mathrm{CP}$ & VFA & NSP \\
\hline Biochemical synthesis* & & & レ & & 98 & 88 & $71 \dagger$ & 78 & \\
\hline Pure nutrient infusions & & & レ & $\boldsymbol{\nu}$ & 95 & 85 & 69 & 75 & \\
\hline Diet sources ( $100 \%$ digestibility) & $\boldsymbol{\nu}$ & & $\boldsymbol{\nu}$ & $\boldsymbol{\nu}$ & 90 & 75 & 57 & 63 & 53 \\
\hline Diet sources (typical digestibility) $\ddagger$ & レ & $\boldsymbol{\nu}$ & $\boldsymbol{\nu}$ & $\boldsymbol{\nu}$ & 89 & 75 & 56 & 63 & 48 \\
\hline Range of reported values (dietary digestible nutrients) & $\nu$ & レ & $\nu$ & $\nu$ & 90 & $74-76$ & $52-65$ & - & $40-60$ \\
\hline
\end{tabular}
efficiencies obtained with the calibrated nutritional process model are in agreement with the range of reported values.

Table 5. Simulated marginal efficiencies of utilizing metabolizable energy (from different nutrient sources) for energy retained in lipid

${ }^{*}$ Also including the urinary excretion cost associated with protein catabolism.

† Value reflects the actual (biological) energetic cost of $\mathrm{N}$ excretion with urine.

¥Digestibilities assumed to be (\%): CFA 80, fCP 85, NSP 60, VFA, ST and SU 100.

ME, metabolizable energy; REL, energy retained in lipid; ATPd, energy requirement for intake, digestion and absorption of nutrients from faecal digestible DM; ATPI, energy requirement for retention of body lipid; ATP $_{\mathrm{x}}$, energy requirement for faecal excretion of non-digestible materials; ATP $_{\mathrm{u}}$, energy requirement for urinary excretion of non-metabolizable materials; CFA, crude fat; ST, starch; CP, crude protein; VFA, volatile fatty acids; f, faecal. 
The values reported in the second line of Table 5 indicate that the observed hierarchy of partial efficiencies (e.g. Noblet \& Henry, 1991; Whittemore, 1997) for deriving REL in growing pigs from CFA, ST, CP or NSP is a consequence of combining biochemical efficiencies with the energy requirements to support the intake process (and also the cost of $\mathrm{N}$ excretion with urine). The actual efficiency values will vary with the energy requirement for lipid retention, but since the same value of ATPl is applied to all nutrients the hierarchy will not be affected by it. Thus, it can be concluded that the hierarchical difference between calculated biochemical efficiencies and observed dietary efficiencies in pigs is primarily a consequence of the energy required to physically process the energy substrate itself, and the assumed relation that this is a function of nutrient mass, rather than energy density. This avoids the necessity for separate costs for Ld derived from diet FA and FA synthesized de novo (e.g. Emmans, 1994), which is seen to be a consequence of including the intake costs in the overall efficiency related to REL, thereby associating it with energy density rather than physical mass density of the nutrients processed.

Noblet et al. $(1989 a, 1994)$ report energy and $\mathrm{N}$ balances for pigs fed sixty-one different experimental diets of widely varied composition at two energy intake levels (high and low). These observations were made to study the quantitative effect of diet nutrient composition on the supply of 'useful' or net energy. The (high level) data represent a valuable source of ME $v$. RE relationships for a wide variety of diet compositions and digestibilities (Birkett $\&$ de Lange, 2001a), which can be used as an independent test of the fully parameterized nutritional process model.

To evaluate the calibration procedure and the parameters determined for growing pigs, simulated diets were created to represent each of the forty-one diets reported in Noblet et al. (1989a), for which treatments detailed data were available. For each diet actual nutrient contents and digestibilities were used in the simulations. Missing diet information was derived from diet ingredient composition and ingredient characteristics according to Centraal Veevoeder Bureau (1998). PdMax was used to force the simulated Pd to match the observed value for each diet treatment, and the corresponding simulated $\mathrm{Ld}$ was recorded. Predicted Ld rates for the forty-one treatments were regressed against the observed $\mathrm{Ld}$ values reported in the dataset. The ATPb parameter was adjusted once across all diets to determine the value which gave the best fit between predicted and observed Ld rates, by minimizing the standard error over the forty-one treatments. The relative hierarchy of $\mathrm{Ld}$ values across the forty-one treatments is not affected by this choice of ATPb, since BW was very similar for all the animals in this study. Figure 3 shows observed $v$. predicted $\mathrm{Ld}$ values obtained using the nutritional process model calibrated with the parameters obtained above. The Ld values ( $n$ 41) have a reasonable standard error of prediction of $7 \mathrm{~g} / \mathrm{d}$.

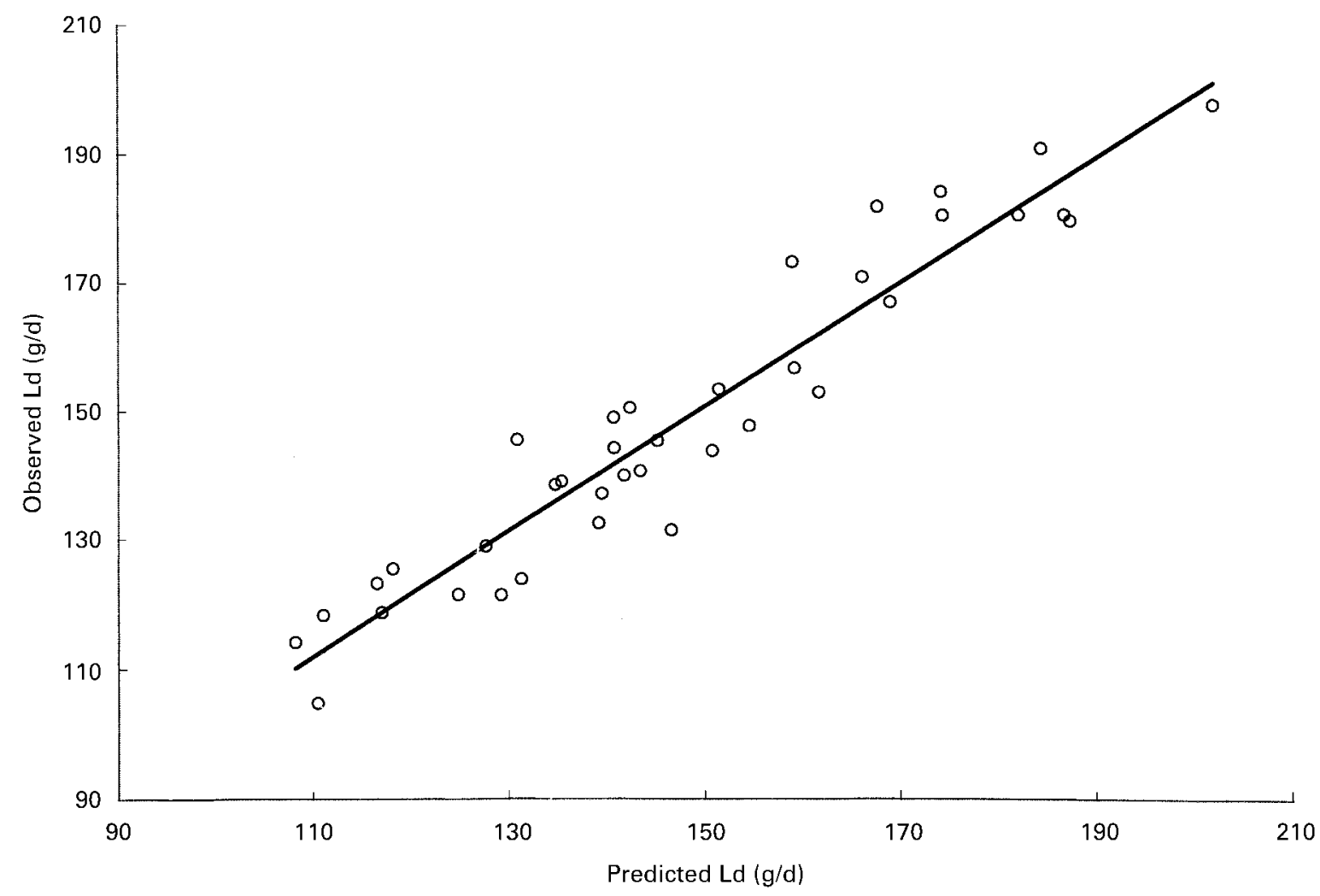

Fig. 3. Lipid retention (Ld) for growing pigs fed forty-one different experimental diets (Noblet et al. 1989a). Predicted $v$. observed Ld values $\left(y=0.97 x+5.45, R^{2} 0.91\right)$. 


\section{Protein and lipid retention}

Combining the energy content of the $\mathrm{Pd}(23.3 \mathrm{~kJ} / \mathrm{g})$ with the energy requirements to support $\mathrm{Pd}$, at an estimated equivalent $\mathrm{ME}$ cost of about $21 \mathrm{~kJ} / \mathrm{g} \mathrm{Pd}$, gives a total $\mathrm{ME}$ cost for protein retention of about $44 \mathrm{~kJ} / \mathrm{g} \mathrm{Pd}$, corresponding to a maximum theoretical biological efficiency for protein accretion of about 0.53 . It can be estimated that about $50 \%$ of the energy required to support $\mathrm{Pd}$ is not related directly to protein synthesis or turnover. In practice $\mathrm{k}_{\mathrm{p}}$ will be reduced to between about 0.47 and 0.51 , depending on the composition and digestibility of the ME as this affects the intake energy requirements and biochemical inefficiency of nutrient transformations. Energy requirements for Ld have an equivalent $\mathrm{ME}$ cost of about $2.5 \mathrm{~kJ} / \mathrm{g} \mathrm{Ld}$, based on a typical molar weight of $900 \mathrm{~g} / \mathrm{mol} \mathrm{Ld}$. Combining this value with the heat of combustion of the $\mathrm{Ld}(39.3 \mathrm{~kJ} / \mathrm{g})$ gives a total minimum ME cost for lipid retention of about $42 \mathrm{~kJ} / \mathrm{g}$ $\mathrm{Ld}$, very close to the value for Pd, and giving a theoretical upper limit of 0.94 for the marginal efficiency of utilizing $\mathrm{ME}$ for REL. In practice $\mathrm{k}_{\mathrm{f}}$ will be reduced by other energy requirements to between about 0.62 to 0.71 for practical pig diets.

Simulated $\mathrm{k}_{\mathrm{f}}$ and $\mathrm{k}_{\mathrm{p}}$ values for ME derived from pig diets of different nutrient composition (Table 6) were calculated using multiple linear regression of model-generated $\mathrm{ME}$ against REL and REP data. Model response in terms of REL and REP is seen to be (essentially) multi-linear with regard to ME intake, therefore one can expect to obtain constant values for $\mathrm{k}_{\mathrm{f}}$ and $\mathrm{k}_{\mathrm{p}}$. Corresponding values for $\mathrm{k}_{\mathrm{g}}=$ $\mathrm{RE} /(\mathrm{ME}-\mathrm{MEm})$ are shown for incremental REL:REP ratios of $1 \cdot 0,2 \cdot 0$, and $3 \cdot 0$. The enhanced energetic efficiency for diets with increased CFA is evident in the increment in $\mathrm{k}_{\mathrm{g}}$ of almost 3 percentage points associated with a moderate increase in CFA content from 3 to $13 \%$. On the other hand a depressive effect on simulated $\mathrm{k}_{\mathrm{g}}$ is seen to be a consequence of increased diet content of either NSP, or $\mathrm{CP}$ of the same AA composition as that of the base diet. A more well-balanced $\mathrm{CP}$ intake, achieved by increasing the essential AA:non-essential AA ratio, enhances $\mathrm{k}_{\mathrm{f}}$, but reduces $\mathrm{k}_{\mathrm{p}}$, with little net effect on $\mathrm{k}_{\mathrm{g}}$. Simulated $\mathrm{k}_{\mathrm{g}}$ is also enhanced by an increased lipid:protein ratio in the gain.
These dietary and animal effects on $\mathrm{k}_{\mathrm{g}}$ are as anticipated and reflect biological reality. In some cases, the increase in $\mathrm{k}_{\mathrm{g}}$ is associated with increases in both $\mathrm{k}_{\mathrm{f}}$ and $\mathrm{k}_{\mathrm{p}}$, as these are affected by the efficiency of generating ATP from nutrient intake. In general, $\mathrm{k}_{\mathrm{f}}$ is more variable than $\mathrm{k}_{\mathrm{p}}$, since it is also affected by alternative pathways for nutrients.

The complexities of interpreting experiments, important statistical issues, assumptions related to MEm, and the fact that REP is often considerably smaller than REL (Birkett \& de Lange, 2001a), are no doubt responsible for considerable variation in experimental estimates of $\mathrm{k}_{\mathrm{p}}$. However, modelgenerated $\mathrm{k}_{\mathrm{p}}$ values avoid these pitfalls to a large extent, and the comparatively small variation in the simulated $\mathrm{k}_{\mathrm{p}}$ values of Table 6 may perhaps more accurately reflect biological reality. Alternatively, a better understanding of the factors which contribute to variation in the rate of protein synthesis as compared to retention, i.e. explicit modelling of protein turnover, might possibly generate more variation in simulated $\mathrm{k}_{\mathrm{p}}$ values. There will always be some uncertainty in the simulated $\mathrm{ME}$ intake value related to the estimate of urinary energy content, an increase in assumed urinary energy density over the range from 33 to $60 \mathrm{~kJ} / \mathrm{g} \mathrm{uN}$ increasing $\mathrm{k}_{\mathrm{f}}$ by 3-5 percentage points, and decreasing $\mathrm{k}_{\mathrm{p}}$ by $1-3$ percentage points. Further unpredictable effects may also result if different urinary energy contents apply at the two intake levels used to derive the incremental intake.

It is important to determine experimental data in the region where the animal's response to nutrient intake is linear. For example, the simulated response surface of ME $v$. REP and REL becomes noticeably curvilinear in the region where Pd is governed by AA limitation. For such situations $\mathrm{k}_{\mathrm{f}}$ and $\mathrm{k}_{\mathrm{p}}$ are not constant and will vary according to an animal's utilization of nutrient intake. Multiple linear regression of ME $v$. REP and REL using experimental data for which some $\mathrm{Pd}$ values are limited by AA intake is therefore not valid, and the non-linear response will affect the interpretation of $\mathrm{k}_{\mathrm{f}}$ and $\mathrm{k}_{\mathrm{p}}$ values. Experimental design and animal utilization of dietary nutrients must be given careful consideration in any examination of marginal energetic efficiencies, particularly when very low intakes are used.

Table 6. Simulated $k_{f}, k_{p}$ and $k_{g}$ values for various practical pig diets ${ }^{*}$

\begin{tabular}{|c|c|c|c|c|c|c|c|c|c|c|}
\hline \multirow[b]{3}{*}{ Diet } & \multirow{2}{*}{\multicolumn{2}{|c|}{$k_{f}$}} & \multirow{2}{*}{\multicolumn{2}{|c|}{$k_{p}$}} & \multicolumn{6}{|c|}{$\mathrm{k}_{\mathrm{g}}(\mathrm{Ld}: \mathrm{Pd}$ ratio $) \dagger$} \\
\hline & & & & & \multicolumn{2}{|c|}{1} & \multicolumn{2}{|c|}{2} & \multicolumn{2}{|c|}{3} \\
\hline & $\%$ & $+l-\ddagger$ & $\%$ & $+/-\ddagger$ & $\%$ & $+/-\ddagger$ & $\%$ & $+l-\ddagger$ & $\%$ & $+l-\ddagger$ \\
\hline Base & $68 \cdot 7$ & & $48 \cdot 8$ & & $59 \cdot 6$ & & $62 \cdot 8$ & & $64 \cdot 4$ & \\
\hline $130 \mathrm{~g} \mathrm{CFA} / \mathrm{kg}$ & $71 \cdot 6$ & $+2 \cdot 9$ & $50 \cdot 5$ & $+1 \cdot 7$ & $62 \cdot 0$ & $+2 \cdot 3$ & $65 \cdot 4$ & $+2 \cdot 5$ & $67 \cdot 0$ & $+2 \cdot 6$ \\
\hline $220 \mathrm{~g} \mathrm{NSP} / \mathrm{kg} \mathrm{0.50 \|}$ & $65 \cdot 9$ & $-2 \cdot 8$ & $47 \cdot 1$ & $-1 \cdot 7$ & $57 \cdot 4$ & $-2 \cdot 3$ & $60 \cdot 4$ & $-2 \cdot 5$ & $61 \cdot 8$ & -2.5 \\
\hline $250 \mathrm{~g} \mathrm{CP} / \mathrm{kg}$ (Lys:CP=0.05) & $66 \cdot 8$ & -1.9 & $47 \cdot 6$ & $-1 \cdot 2$ & $58 \cdot 1$ & $-1 \cdot 6$ & $61 \cdot 2$ & $-1 \cdot 7$ & $62 \cdot 6$ & -1.7 \\
\hline $130 \mathrm{~g} \mathrm{CP} / \mathrm{kg}$ (Lys:CP=0.06)§ & $70 \cdot 0$ & $+1 \cdot 3$ & $47 \cdot 6$ & $-1 \cdot 2$ & $59 \cdot 6$ & -0.1 & $63 \cdot 2$ & +0.4 & $65 \cdot 0$ & $+0 \cdot 6$ \\
\hline
\end{tabular}

Ld, lipid retained; Pd, protein retained; CFA, crude fat; CP, crude protein; Lys, lysine.

* For details of composition of maize-soyabean base diet $(175 \mathrm{~g} \mathrm{CP} / \mathrm{kg})$, see Table 4 . Other diets were formulated by adjusting the ST content to achieve the stated nutrient level.

$\dagger k_{g}$ values shown at three levels of $L d: P d$ ratio $(1,2$ and $3 \mathrm{~g} / \mathrm{g})$.

$\ddagger+l$ - denotes percentage increment with regard to values for base diet.

$\S$ Non-essential amino acids replaced with starch.

\| Assumed $50 \%$ digestible. 


\section{Influence of digestibility}

As discussed in Birkett \& de Lange (2001a), the high intake level data of Noblet et al. (1989a) exhibit a diet quality bias, with a positive correlation between digestibility and feed intake. To illustrate the importance of ATPx, simulated Ld values were calculated for these forty-one high intake level dietary treatments, with ATPx set to zero and all other calibrated parameters unchanged. Under these conditions, i.e. ignoring the effects of $\mathrm{xDM}$ on efficiency, a slope of only $0.90\left(R^{2} 0.90\right)$ is obtained in a linear regression of predicted against observed Ld values, as compared with a slope of $0.95\left(R^{2} \quad 0.91\right)$ obtained when the properly calibrated value for ATPx is used. Therefore, it can be concluded that the increased heat production associated with the lower quality, less digestible, diets cannot be completely predicted without considering the effects of nondigested material, thus confirming the essential significance of the ATPx parameter.

Energy requirements for processing non-digested material have an equivalent ME cost of about $1.5 \mathrm{~kJ} / \mathrm{g}$ xDM. The independently derived parameters ATPx and ATPd are consistent and their ratio $(0 \cdot 70)$ is biologically realistic and consistent with the definitions of the processes they drive. Emmans (1994) derives an ME cost for faecal organic matter of $3.8 \mathrm{~kJ} / \mathrm{g}$ faecal organic matter, using data derived for cattle and poultry, extrapolating this to all species. In particular, the estimate is not based on a direct estimate for pigs (GC Emmans, personal communication). This ME cost of faecal organic matter is more than twice the equivalent $\mathrm{ME}$ cost estimated for processing $\mathrm{xDM}$ in the nutritional process model.

The effect of nutrient faecal digestibility on simulated marginal energetic efficiencies of utilizing different types of digestible nutrients for Ld are shown in Table 7 for various extreme diets in Noblet et al. (1989a). The high energy density of CFA constrains variation in $\mathrm{k}_{\mathrm{f}}$ to a narrow range between 0.85 to 0.89 , despite a very wide range of digestibilities from 38 to $75 \%$. As a consequence of its low energy density, digestible NSP shows a large variation in $\mathrm{k}_{\mathrm{f}}$ between 0.21 and 0.49 , due to the effect of digestibility ranging from 19 to $67 \%$. For $\mathrm{CP}$ the $\mathrm{k}_{\mathrm{f}}$ of about 0.56 is largely unaffected by variation in $\mathrm{CP}$ digestibility over the typical narrow range of 70 to $94 \%$. However, the assumed urinary energy density used in the calculation of ME intake has a major influence on the simulated $\mathrm{k}_{\mathrm{f}}$ value for $\mathrm{CP}$, which varies from 0.50 if a low $33 \mathrm{~kJ} / \mathrm{g} \mathrm{uN}$ is used, to 0.65 if

Table 7. Effect of faecal digestibility on simulated partial efficiency $k_{f}$ for various nutrients

\begin{tabular}{llllll}
\hline & \multicolumn{2}{c}{$\begin{array}{c}\text { Faecal } \\
\text { digestibility }\end{array}$} & & \multicolumn{2}{c}{ Simulated $k_{f}$} \\
\cline { 2 - 3 } & Min & Max & & Min & Max \\
\hline CFA & 0.38 & 0.75 & & 0.85 & 0.89 \\
NSP & 0.19 & 0.67 & & 0.21 & 0.49 \\
CP & 0.70 & 0.94 & & 0.56 & 0.57 \\
\hline
\end{tabular}

Min, minimum; Max, maximum; CFA, crude fat; $\mathrm{CP}$, crude protein. urinary energy is a high $60 \mathrm{~kJ} / \mathrm{g} \mathrm{uN}$. This is a consequence of the relatively high energy requirement to support urinary excretion ( $\mathrm{ATPu}$ ), which is equivalent to an $\mathrm{ME}$ cost varying between 1 and $5 \%$ total ME intake in the diets of Noblet et al. (1989a). The fraction of a digestible nutrient intake which is fermented has a significant influence on simulated $\mathrm{k}_{\mathrm{f}}$ values. For example $\mathrm{k}_{\mathrm{f}}$ for $\mathrm{SU}$ varies from 0.64 to 0.74 as a consequence of varying the fraction of $\mathrm{SU}$ that is enzymatically digested as opposed to fermented over the range of 60 to $97 \%$. These latter values were estimated from ingredient characterizations according to Centraal Veevoeder Bureau (1998), since ileal SU digestibilties were not determined by Noblet et al. (1989a).

\section{Maintenance energy requirements}

Tess (1981) gives a review of literature values of maintenance energy requirements and fasting heat production. Variation in reported MEm can be attributed to various experimental or statistical reasons (Birkett \& de Lange, 2001a). In addition, metabolic factors can influence the relationship between MEm and BW, for example those which affect the efficiency of utilization of nutrients for generating ATP, such as diet composition, or which affect the lipid:protein ratio in the gain, such as feeding level, BW, AA intake, or pig genotype. Typical values for MEm in growing pigs are reported in the range $800-900 \mathrm{~kJ} / \mathrm{kg}^{0.60}$ per d, for instance $825 \mathrm{~kJ} / \mathrm{kg}^{0.60}$ per d (Agricultural Research Council, 1981; Quiniou, 1995), although values as large as $1000 \mathrm{~kJ} / \mathrm{kg}^{0.60}$ per d have been suggested (Noblet et al. 1991). For the purpose of facilitating comparison between MEm values from various sources, which are expressed with metabolic BW exponents ranging from 0.54 to 0.75 , values were converted to a common metabolic $\mathrm{BW}$ exponent of 0.60 (using a basis of $50 \mathrm{~kg} \mathrm{BW}$ ).

The effect on MEm due to variation in partitioning ME intake can be illustrated by calculating MEm from model simulations, at various BW and for pigs with different $\mathrm{Pd}$ values. A BE value of $1.3 \times$ BEmin, typical for pigs kept under on-farm production conditions, was assumed. Modelgenerated values of MEm, calculated as:

$$
\mathrm{MEm}=\mathrm{ME}-\mathrm{REL} / \mathrm{k}_{\mathrm{f}}-\mathrm{REP} / \mathrm{k}_{\mathrm{p}}
$$

are shown in Table 8 , for BW of $20,50,80$, and $110 \mathrm{~kg}$, using ME derived from the base diet of Table 4, with efficiencies of $k_{f}=0.69$ and $k_{p}=0.49$. The simulated values are consistent with reported values (Agricultural Research Council, 1981; Quiniou, 1995). The two pig types shown in Table 8, low $v$. high Pd, have different simulated MEm at the same BW, on account of the difference in lipid:protein ratio in the gain, and its effect on the efficiency $\left(\mathrm{k}_{\mathrm{g}}\right)$ of nutrient utilization for RE. To illustrate the dependence of MEm on diet composition, simulated MEm values were generated for diets with various changes to the nutrient composition of the base diet: (1) with $100 \mathrm{~g} \mathrm{ST} / \mathrm{kg}$ replaced by CFA, MEm was about $4 \%$ lower than those shown in Table 8; (2) with CP increased to $250 \mathrm{~g} / \mathrm{kg}$ at the expense of ST, and no change in the AA composition of $\mathrm{CP}$, MEm was increased by about 4\%; (3) with $100 \mathrm{~g} \mathrm{ST} / \mathrm{kg}$ replaced by crude fibre (faecal digestibility $0 \cdot 50$ ), MEm was 
Table 8. Simulated metabolizable energy for maintenance requirement (MEm) at four live body weights for two pig genotypes* $\dagger$

\begin{tabular}{|c|c|c|c|c|c|c|c|c|}
\hline & \multicolumn{8}{|c|}{ Mem‡ } \\
\hline & \multicolumn{4}{|c|}{$\mathrm{BW}(\mathrm{kg} / \mathrm{Pd} 135 \mathrm{~g} / \mathrm{d}$} & \multicolumn{4}{|c|}{$\mathrm{BW}(\mathrm{kg} / \mathrm{Pd} 220 \mathrm{~g} / \mathrm{d}$} \\
\hline & 20 & 50 & 80 & 110 & 20 & 50 & 80 & 110 \\
\hline $\mathrm{MJ} / \mathrm{d}$ & $5 \cdot 2$ & 8.6 & $10 \cdot 9$ & $13 \cdot 0$ & $5 \cdot 0$ & 8.5 & 11.5 & $13 \cdot 6$ \\
\hline $\mathrm{kJ} / \mathrm{d}$ per kg BW ${ }^{0.75}$ & 550 & 460 & 410 & 380 & 530 & 450 & 430 & 400 \\
\hline $\mathrm{kJ} / \mathrm{d}$ per $\mathrm{kg} \mathrm{BW}^{0.60}$ & 860 & 820 & 790 & 780 & 830 & 810 & 830 & 810 \\
\hline $\mathrm{kJ} / \mathrm{d}$ per kg BW $\mathrm{BW}^{0.54}$ & 1000 & 1000 & 1000 & 1000 & 1000 & 1000 & 1100 & 1100 \\
\hline
\end{tabular}

BW, body weight; $P d$, protein retained; Ld, lipid retained.

${ }^{*}$ Basal free energy expenditure $(B E)=1.3 \times B E m i n$, where BEmin $=23.8 \times$ body protein $(\mathrm{kg})^{0.54}$

† For details of composition of diet, see Table 4 (diet was fed at $90 \%$ ad libitum intake, according to the National Research Council (1987)).

$\ddagger$ MEm calculated as ME intake $-R E L / k_{f}-R E P / k_{p}$ with $k_{p}=0.69$ and $k_{p}=0.49$, where ME is metabolizable energy intake, REL is energy retained in lipid and REP is energy retained in protein.

increased by $3 \%$. These simulated variations in MEm are related only to changes in metabolic and biochemical processes and their associated energy requirements and efficiencies.

In experiments with pigs under fasting conditions long enough to achieve a stable heat production, van Es (1972) reports an estimated fasting heat production equivalent to $575 \mathrm{~kJ} / \mathrm{d} / \mathrm{kg}^{0 \cdot 60}$. In a series of experiments designed to measure fasting heat production in six different genotypes of pigs, van Milgen et al. (1998) report fasting heat production values of about $700 \mathrm{~kJ} / \mathrm{kg}^{0.60}$ per $\mathrm{d}$, when corrected to resting conditions. In comparison, BE requirements obtained for simulated experiments are generally in the range of 7.3 to $8.3 \mathrm{~mol} \mathrm{ATP} / \mathrm{kg}^{0.60}$ per d, and BEmin is equivalent to about $7 \cdot 1 \mathrm{~mol} \mathrm{ATP} / \mathrm{kg}^{0 \cdot 60}$ per d. Thus, model-generated $\mathrm{BE}$ is generally in the range of about 7-8 mol ATP $/ \mathrm{kg}^{0.60}$ per $\mathrm{d}$, equivalent to free energy requirement in the range from 360 to $420 \mathrm{~kJ} / \mathrm{kg}^{0 \cdot 60}$ per $\mathrm{d}$. This range of free energy values is consistent with the definition of $\mathrm{BE}$ and the range of heat production estimates reported for fasting heat production $\left(600-700 \mathrm{~kJ} / \mathrm{kg}^{0.60}\right.$ per d) and $\mathrm{MEm}$ (800 to $900 \mathrm{~kJ} / \mathrm{kg}^{0 \cdot 60}$ per d).

\section{Conclusions}

A calibration procedure has been described that can be used to adjust the marginal and absolute energetic response of a nutritional process model to match the response of growing pigs to nutrient intake. The parameters obtained are intended to be reasonable estimates, however further studies will be required for a more definitive calibration. The values given illustrate that the calibration procedure is capable of parameterizing the model effectively and meaningfully, as shown by the evaluation of simulated response against independent datasets.

Models based on factorial analysis of ME intake emphasize animal response, but cannot account for variation in the contribution of the various nutrients to energy intake. Current net energy systems can account for variation in dietary nutrient composition, but not in the animal's utilization of that net energy intake. The calibrated nutritional process model described here can account for variation in both dietary nutrient composition and metabolic utilization of nutrient intake. Linear programming optimization methods for least cost feed formulation are no longer possible with the nutrient process model, since the net energy supplied by feed ingredients is not constant for a given nutrient composition and will vary according to the use of nutrients for the various body functions. However, the integration of feed formulation with animal response provided by the new model provides a different, more sophisticated optimization capability.

This nutritional process model represents animal biology explicitly, thereby associating heat production with biological reality and the various processes which are responsible for it. The well-known hierarchy of biological marginal energetic efficiencies for $\mathrm{Ld}$ derived from different nutrient classes can be predicted by the model, as a consequence only of energy density, digestibility, and biochemical stoichiometry.

\section{Acknowledgements}

Sincere appreciation is given for the financial support of Agribrands International for the research related to this article. The authors would like to thank Paul Moughan, Martin Verstegen, Patrick Morel and Bruno Marty for their contributions to the development of the concepts. Valuable discussions with Jean Noblet are also gratefully appreciated.

\section{References}

Agricultural Research Council (1981) The Nutrient Requirements of Pigs. London: Commonwealth Agricultural Bureaux.

Armstrong DG (1969) Cell bioenergetics and metabolism. In Handbuch der Tierernährung (Band 1) (Handbook of Animal Nutrition). pp. 385-414 [W Lenkheit, K Breirem and E Crasemann, editors]. Hamburg: Paul Parey.

Bakker G (1996) Interaction between carbohydrates and fat in pigs. $\mathrm{PhD}$ Thesis, Wageningen Agricultural University.

Birkett S \& de Lange K (2001a) Limitations of conventional models and a conceptual framework for a nutrient flow representation of energy utilization by animals. British Journal of Nutrition 86, 647-659.

Birkett S \& de Lange K (2001b) A computational framework for a nutrient flow representation of energy utilization by growing monogastric animals. British Journal of Nutrition 86, 661-674. 
Black JL (1995) Modelling energy metabolism in the pig critical evaluation of a simple reference model. In Modelling Growth in the Pig, EAAP Publication no. 78, pp. 87-102 [PJ Moughan, MWA Verstegen and MI Visser-Reyneveld, editors]. Wageningen: Wageningen Pers.

Blaxter KL (1989) Energy Metabolism in Animals and Man. Cambridge: Cambridge University Press.

Boyd J \& McCracken KJ (1979) Effect of dietary fat level and composition on fat and protein retention and efficiency of energy utilization by male castrate pigs between 13 and $40 \mathrm{~kg}$ live weight. In Energy Metabolism, Proceedings of the Eighth Symposium on Energy Metabolism, Cambridge, September, 1979, pp. 111-114 [L Mount, editor]. London: Butterworths.

Burton K (1958) Energy of adenosine triphosphate. Nature 181, $1594-1595$.

Centraal Veevoeder Bureau (1998) Veevoedertabel (Table of Feeding Value of Animal Feed Ingredients). Lelystad: Centraal Veevoeder Bureau.

Close WH, Verstegen MWA \& Mount LE (1973) The energy costs of maintenance and production in the growing pig. Proceedings of the Nutrition Society 32, 72A.

Critical Reviews in Chemistry (1996) CRC Handbook of Chemistry and Physics. Table of Enthalpies, 77th ed. Boca Raton, FL: CRC Press.

de Lange CFM \& Schreurs HWE (1995) Principles of model application. In Modelling Growth in the Pig, EAAP publication no. 78, pp. 187-208 [PJ Moughan, MWA Verstegen and MI Visser-Reyneveld, editors]. Wageningen: Wageningen Pers.

Emmans GC (1994) Effective energy: a concept of energy utilization applied across species. British Journal of Nutrition 71, 801-821.

Fuller MF (1994) Amino acid requirements for maintenance, body protein accretion and reproduction in pigs. In Amino Acids in Farm Animal Nutrition, pp. 155-184 [JDF D'Mello, editor]. Wallingford: $\mathrm{CAB}$ International.

Gädeken D, Breves G \& Oslage H (1989) Efficiency of energy utilization of intracaecally infused volatile fatty acids in pigs. In Energy Metabolism of Farm Animals, Proceedings of the Eleventh Symposium, Lunteren, Netherlands, 18-24 September, 1988, EAAP publication no. 43, pp. 115-118 [Y van der Honing and WH Close, editors]. Wageningen: Pudoc.

Hoffmann L \& Klein M (1980) Die Abhaengigkeit der Harnenergie vom Kohlenstoff- und Stickstoffgehalt in Harn bei Rindern, Schafen, Schweinen und Ratten (Urinary energy as a function of the carbon and nitrogen content of cattle, sheep, pig and rat urine). Archiv für Tierernährung 30, 743-750.

Jentsch W, Schiemann R \& Hoffmann L (1988) About the utilization of metabolizable energy in pigs when nutrients are digested precaecally or postileally. In Proceedings of the Fourth International Seminar on Digestive Physiology in the Pig, pp. 148-154 [S Buraczewski, B Pastuszewska and T Zebrowska, editors]. Jablonna: Polish Academy of Sciences.

Jorgensen H, Jakobsen K \& Eggum BO (1992) The influence of different protein, fat and mineral levels on the digestibility of fat and fatty acids measured at the terminal ileum and in faeces of growing pigs. Acta Agriculturae Scandinavica 42, 177-184.

Jorgensen H, Jakobsen K \& Eggum BO (1993) Determination of endogenous fat and fatty acids at the terminal ileum and on faeces in growing pigs. Acta Agriculturae Scandinavica 43, $101-106$.

Jorgensen H, Zhao X-Q \& Eggum BO (1996) The influence of dietary fibre and environmental temperature on the development of the gastrointestinal tract, digestibility, degree of fermentation in the hind-gut and energy metabolism in pigs. British Journal of Nutrition 75, 365-378.

Kielanowski J (1971) Energy requirements of the growing pig. In Pig Production, Proceedings of the Eighteenth Easter School in
Agricultural Science, Nottingham, 1971, pp. 183-201 [DJA Cole, editor]. London: Butterworth.

Kirchgeßner M \& Müller HL (1991) Energy utilization via hindgut fermentation in pigs. In Digestive Physiology of the Hindgut. Advances in Animal Physiology and Animal Nutrition 22, $41-49$.

Kirchgeßner M, Kreuzer M, Müller HL \& Windisch W (1991) Release of methane and carbon dioxide by the pig. Agribiological Research 44, 103-113.

Knox KL (1979) Energy metabolism. Comparative Animal Nutrition 3, 1-33.

Kyriazakis I \& Emmans GC (1992) The effects of varying protein and energy intakes on the growth and body composition of pigs. 1 The effects of energy intake at constant, high protein intake. British Journal of Nutrition 68, 603-613.

Kyriazakis I, Emmans GC \& McDaniel R (1993) Whole body amino acid composition of the growing pig. Journal of the Science of Food and Agriculture 62, 29-33.

Longland A, Close W \& Low A (1989) The role of the large intestine in influencing the use of fibrous feeds in pigs. In Energy Metabolism of Farm Animals, Proceedings of the Eleventh Symposium, Lunteren, Netherlands, 18-24 September 1988, EAAP publication no. 43, pp. 111-114 [Y van der Honing and W Close, editors]. Wageningen: Pudoc.

McDonald P, Greenhalgh JFD, Edwards RA \& Morgan CA (1995) Animal Nutrition (fifth ed.). New York, NY: Longmans.

Moughan PJ (1999) Protein metabolism in the growing pig. In $A$ Quantitative Biology of the Pig, pp. 299-332 [I Kyriazakis, editor]. Wallingford: CAB International.

Müller H \& Kirchgeßner M (1982) Effect of straw and cellulose on heat production and energy utilization in pigs. In Energy Metabolism of Farm Animals, Proceedings of the Ninth Symposium, Lillehammer, Norway, September 1982, EAAP publication no. 29, pp. 229-232 [A Eckern and F Sundstol, editors]. Aas-Nlh, Norway: Agricultural University of Norway.

Müller H \& Kirchgeßner M (1991) Further studies on energy utilization via hindgut fermentation. In Proceedings of the Twelfth Symposium on Energy Metabolism, Zurich, Switzerland, EAPP publication no. 58, pp. 134-137 [C Wenk and M Boessinger, editors]. Zurich, Switzerland: Institute for Animal Science, Nutrition Group Library, Swiss Federal Institute of Technology.

National Research Council (1987) Predicting Feed Intake of FoodProducing Animals. Washington, DC: National Academy Press.

Nehring K, Schiemann R, Hoffmann L, Klippel W \& Jentsch W (1965) Utilization of the energy of cellulose and sucrose by cattle, sheep and pigs. In Proceedings of the Third Symposium on Energy Metabolism of Farm Animals, Troon, EAPP publication no. 11, pp. 249. London, New York: Academic Press.

Noblet J, Fortune H, Dubois S \& Henry Y (1989a) Nouvelles Bases d'Estimation des Teneurs en Energie Digestible, Metabilisable et Nette des Aliments pour le Porc (New Basis for Estimation of Digestible and Metabolizable Net Energy in Swine Feeds). Saint Gilles: INRA.

Noblet J, Fortune H, Shi XS \& Dubois S (1994) Prediction of net energy values of feeds for growing pigs. Journal of Animal Science 72, 344-354.

Noblet J \& Henry Y (1991) Energy evaluation systems for pig diets. In Manipulating Pig Production III, Proceedings of the Third Biennial Conference of the Australasian Pig Science Association (APSA), Albury, NSW, November. 24-27, 1991, pp. 87-110 [ES Batterham, editor]. Victoria: APSA.

Noblet J, Karege C \& Dubois S (1989b) Influence of sex and genotype on energy utilization in growing pigs. In Energy Metabolism of Farm Animals, Proceedings of the Eleventh Symposium, Lunteren, The Netherlands, 18-24 September 
1988, EAAP publication no. 43, pp. 57-60 [Y van der Honing and WH Close, editors]. Wageningen: Pudoc.

Noblet J, Karege C \& Dubois S (1991) Influence of growth potential on energy requirements for maintenance in growing pigs. In Energy Metabolism of Farm Animals, EAAP publication no. 58, pp. 107-110 [C Wenk and M Boessinger, editors]. Zurich: ETH.

Pullar JD \& Webster AJF (1977) The energy cost of fat and protein deposition in the rat. British Journal of Nutrition 37, $355-363$.

Quiniou N (1995) Utilization de l'Energie chez le Porc Selon son Potentiel de Croissance: Contribution à la Modelisation des Besoins Nutritionnels et de la Composition Corporelle (Utilization of Energy by the Pig According to Growth Potential: Contribution to the Modelling of Nutritional Requirements and Body Composition). PhD Thesis, L'Ecole Nationale Superieure Agronomique de Rennes.

Reeds PJ, Cadenhead A, Fuller MF, Lobley GE \& McDonald JD (1980) Protein turnover in growing pigs. Effects of age and food intake. British Journal of Nutrition 43, 445-455.

Roth F, Kirchgeßner M \& Müller H (1988) Energetische Verwertung von intracaecal infundierter Essig-und Propionsaeure bei Sauen (Energy Utilization in the Production of Intracaecal Acetic and Propionic Acid in the Pig). Journal of Animal Physiology A. Animal Nutrition 59, 211-217.

Schiemann R, Hoffmann L, Jentsch W \& Beyer M (1989) Investigations on the energetic utilization of rations with a high variation in the content of different carbohydrate fractions in adult pigs. In Energy Metabolism of Farm Animals, Proceedings of the Eleventh Symposium, Lunteren, Netherlands, 18-24
September, 1988, EAAP publication no. 43, pp. 316-319 [Y van der Honing and WH Close, editors]. Wageningen: Pudoc.

Schultz AR (1978) Simulation of energy metabolism in the singlestomached animal. British Journal of Nutrition 39, 235-254.

Tess M (1981) Simulated Effects of Genetic Change upon LifeCycle Production Efficiency in Swine and the Effects of Body Composition upon Energy Utilization in the Growing Pig. PhD Thesis: University of Nebraska.

van Es AJH (1972) Maintenance. In Handbuch der Tierernährung (Handbook of Animal Nutrition), [W Lenkeit, K Brierem and E Crasemann, editors]. Hamburg: Paul Parey.

van Es AJH (1980) Energy cost of protein deposition. In Protein Deposition in Animals, pp. 215-224 [P Buttery and D Lindsay, editors]. London: Butterworths.

van Milgen J, Bernier JF, Lecozler Y, Dubois S \& Noblet J (1998) Major determinants of fasting heat production and energetic cost of activity in growing pigs of different body weight and breed/castration combination. British Journal of Nutrition 79, $1-9$.

van Milgen J, Noblet J \& Dubois S (2001) Energetic efficiency of starch, protein and lipid utilization in growing pigs. Journal of Nutrition 131, 1309-1318.

Webster AJ, Lobley DE, Reeds PJ \& Pullar JD (1979) Protein mass, protein synthesis and heat loss in the Zucker rat. In Energy Metabolism, Proceedings of the Eighth Symposium on Energy Metabolism, Cambridge, September, 1979, pp. 125-128 [L Mount, editor]. London: Butterworths.

Whittemore CT (1997) An analysis of methods for the utilisation of net energy concepts to improve the accuracy of feed evaluation in diets for pigs. Animal Feed Science Technology $\mathbf{6 8}$, 89-99. 